\title{
Making Sense of Whole Woman's Health v. Hellerstedt: The Development of a New Approach to the Undue Burden Standard
}

\author{
Meghan Harper*
}

\section{INTRODUCTION}

"Undue Burden." This is the single phrase that has shaped the landscape of abortion jurisprudence for the past twenty-five years. ${ }^{1}$ With these two, unclear words, the Supreme Court heightened support for the state's ability to regulate a woman's access to abortion. ${ }^{2}$ However, as courts have worked to decipher what constitutes an undue burden, legislatures have worked around the phrase's vagueness to continually chip away at a woman's right to an abortion. ${ }^{3}$ Without clarification on the meaning of undue burden, the phrase has served as a mechanism for increasing the number and type of regulations that restrict abortion access.

In 2014, approximately 926,200 abortions were performed, ${ }^{4}$ and 788 abortion clinics operated in the United States. ${ }^{5}$ While abortions remain a

\footnotetext{
* J.D. Candidate, 2018, University of Kansas School of Law; B.S.B.A., 2015, Creighton University. I would like to thank Professor Richard Levy for his invaluable feedback and guidance throughout the writing process, as well as all the members of the Kansas Law Review for their hard work and thoughtful review of this comment. I would also like to thank my family and friends for all their patience and support during this process.

1. See Planned Parenthood of Se. Pa. v. Casey, 505 U.S. 833, 874 (1992) (plurality opinion) (citations omitted) (creating the test for the Constitutionality of an abortion regulation as one that determines whether there is an "undue burden on a woman's ability to make [a decision regarding an abortion]"); see also infra Part II.A.

2. See Gillian E. Metzger, Note, Unburdening the Undue Burden Standard: Orienting Casey in Constitutional Jurisprudence, 94 COLUM. L. REV. 2025, 2025 (1994) (arguing that the Court's failure to describe methods to determine the existence of an undue burden on abortion made the protection of a woman's right to a pre-viability abortion unclear); see also Leading Case, Fourteenth Amendment-Due Process Clause-Undue Burden-Whole Woman's Health v. Hellerstedt, 130 HARV. L. Rev. 397, 397 (2016) (noting that after Planned Parenthood of Southeastern Pennsylvania v. Casey, "[w] hat exactly constituted an undue burden was unclear[]") [hereinafter Harvard Leading Case Comment].

3. See infra notes 6-8 and accompanying text.

4. Fact Sheet, Guttmacher Institute, Induced Abortion in the United States (Jan. 2017), https://www.guttmacher.org/fact-sheet/induced-abortion-united-states.
}

5. Id. 
prominent option for women wanting to terminate a pregnancy, legislatures have enacted almost 300 abortion regulations since $2011 .^{6}$ In conjunction with these additional regulations, abortion clinics have been closing at a record pace, even in states considered to be "abortionfriendly." Currently, a woman in the United States waits an average of 8.5 days to receive an abortion appointment. ${ }^{8}$ Thus, with the influx of abortion opponents taking measures to limit access to abortion, the extent of the abortion right hangs in the balance.

Since the 1973 seminal case Roe v. Wade established a woman's right to an abortion, ${ }^{9}$ the subject has been a topic of controversy. As such, the landscape of abortion jurisprudence frequently fluctuates. A woman's right to have an abortion has gone from being a fundamental right-requiring evaluation of laws impacting the right under strict scrutiny - to a protected liberty interest-requiring a nuanced, everchanging, and oftentimes misunderstood form of scrutiny. ${ }^{10}$ The uncertainty of the undue burden analysis - first articulated in Planned Parenthood v. Casey ${ }^{11}$ - has led the Supreme Court and lower courts to grapple with how to appropriately apply the undue burden test. However, a clear method of evaluating Casey's undue burden analysis has not emerged. Instead, each new decision on the constitutionality of abortion legislation comes with new approaches that complicate, rather than clarify, the proper approach to abortion jurisprudence.

This confusion has continued for over twenty years since Casey. On June 27, 2016, the Supreme Court added to this perplexing jurisprudence when it struck down Texas abortion regulations in its most significant decision in two decades, Whole Woman's Health v. Hellerstedt. ${ }^{12}$ Not only does this decision represent continued recognition of the importance

6. Esmé E. Deprez, U.S. Abortion Rights Fight, BLOOMBERG (July 7, 2016), http://www.bloomberg.com/quicktake/abortion-and-the-decline-of-clinics.

7. Danielle Paquette, Why Abortion Clinics in the U.S. Are Rapidly Closing, WASH. Post; WONKBLOG (Feb. 25, 2016), https://www.washingtonpost.com/news/wonk/wp/2016/02/25/whyamericas-abortion-clinics-are-rapidly-closing/.

8. Cheryl Sullenger, Special Report: 2015 Abortion Clinic Survey Reveals 81\% of Abortion Clinics Closed Since 1991, OpERATION Rescue (Dec. 22, 2015), http://www.operationrescue.org/ archives/special-report-2015-abortion-clinic-survey-reveals-81-of-abortion-clinics-closed-since$1991 /$.

9. 410 U.S. 113, 154 (1973).

10. See infra, Part II (discussing the history of abortion jurisprudence).

11. 505 U.S. 833, 874 (1992) (plurality opinion).

12. 136 S. Ct. 2292 (2016); see also Harvard Leading Case Comment, supra note 2 at 405-06 (noting that while Whole Woman's Health has started to clarify how to apply the undue burden standard to health-justified abortion regulations, it is not clear how well the opinion will translate to restrictions "that fit less neatly into a cost-benefit framework"). 
of protecting a woman's abortion right, but it also provides guidance on the appropriate application of the undue burden standard. By demonstrating approval of a balancing test, ${ }^{13}$ Whole Woman's Health begins to clarify how to analyze an undue burden and lends itself to an appropriate revision of the process courts use to evaluate the constitutionality of abortion regulations. Specifically, drawing from the Court's analysis in Whole Woman's Health, this Comment argues that determining an abortion regulation's constitutionality should begin with scrutiny of the purpose under a heightened form of rational basis and conclude with a balancing test of the regulation's burdens and benefits to account for the relationship between the law's purpose and effects. This reflects a protection of a woman's liberty interest in her right to an abortion that follows court precedent and fits within the realm of broader liberty-interest jurisprudence.

Part II of this Comment discusses the history of abortion jurisprudence in the United States-focusing on the development of the undue burden test, contradictory approaches to the test, and an in-depth explanation of the Court's balancing approach in Whole Woman's Health. Part III explains that, following Whole Woman's Health, the most workable and appropriate form of the undue burden standard is a "Rational Basis with Bite Balancing Test" law passes the more stringent rational basis with bite test and then considers whether the benefits created by the law outweigh any burden the law places on a woman's access to an abortion. Additionally, Part III explains how to apply the Rational Basis with Bite Balancing Test and illustrates an application of the test to dismemberment abortion bans to demonstrate how the test protects a woman's liberty interest in the right to an abortion by appropriately determining when undue burdens exist.

\section{BACKGROUND}

Although the heart of abortion jurisprudence spans less than fifty years, controversial decisions and alternating approaches to analyzing the constitutionality of laws permeate this timeframe. Initially recognized as

\footnotetext{
13. See infra, Part II.B.3.

14. Victor Rosenblum, a Northwestern University School of Law professor, is credited with creating the phrase "rational basis with teeth." See David O. Stewart, A Growing Equal Protection Clause?, A.B.A. J., Oct. 1985, 108, 112, 114 (1985). "Rational basis with bite" is used more frequently than "rational basis with teeth" to refer to the application of this heightened scrutiny. See Gerald Gunther, Foreword: In Search of Evolving Doctrine on a Changing Court: A Model for a Newer Equal Protection, 86 HARV. L. REV. 1, 12 (1972) ("Moreover, the outcomes of the fifteen basic cases suggest that the equal protection clause retains considerable bite.”).
} 
a fundamental right subject to the most rigorous scrutiny, a woman's right to an abortion has transformed into a liberty interest. With this transformation, the Supreme Court developed the undue burden standard to determine whether a law violates the liberty interest in a right to an abortion. Courts, however, have struggled to decipher and apply the test for an undue burden consistently. ${ }^{15}$ This opened the door for the Supreme Court in Whole Woman's Health to clarify the method for evaluating the constitutionality of abortion laws - the use of a balancing test.

\section{A. The Creation of the Undue Burden Standard}

Courts have not always used the undue burden standard. Instead, the standard developed as the Supreme Court refined abortion jurisprudence through decisions on various types of abortion laws. Beginning with Roe $v$. Wade, the Supreme Court began creating current abortion jurisprudence and paved the way for establishing the undue burden standard.

\section{The Beginning of Current Abortion Jurisprudence in Roe v. Wade}

In 1973, the Supreme Court decided Roe v. Wade. ${ }^{16}$ This decision marked the first of many momentous outcomes that altered abortion jurisprudence. Heralded as the key, but probably most controversial, decision for abortion rights, Roe v. Wade recognized that the right to terminate a pregnancy is within the fundamental right to privacy protected by the Fourteenth Amendment's Due Process Clause. ${ }^{17}$ The Supreme Court held the Constitution protects the right to terminate a pregnancy prior to viability-when a fetus can survive outside the womb. $^{18}$

By finding women have the fundamental right to pre-viability abortions, the Court had to resolve how to protect this right. Under the jurisprudence at the time, laws affecting the fundamental right to privacy were subject to strict scrutiny. ${ }^{19}$ Therefore, once the Court determined

15. See Metzger, supra note 2, at 2035-38 (discussing the weaknesses in the undue burden standard, and specifically noting that "the failure to develop a methodical analysis of the undue burden standard perpetuates the inconsistency of rulings on abortion").

16. 410 U.S. 113 (1973)

17. Id. at 153 .

18. Id. at $163-64$.

19. See id. at 155 ("Where certain 'fundamental rights' are involved, the Court has held that regulation limiting these rights may be justified only by a 'compelling state interest,' and that 
the right to privacy encompassed a woman's right to terminate her pregnancy, it followed that abortion regulations would be subject to strict scrutiny. ${ }^{20}$ Thus, regulations limiting the abortion right could only be justified by a compelling state interest and needed to be narrowly tailored to achieve the interest. ${ }^{21}$ The Court clarified, however, that the right to an abortion "is not absolute and is subject to some limitations" and that states retain some interest in protecting women's health. ${ }^{22}$ This resulted in the Court dividing the pregnancy into three trimesters to specify the extent of the right - during the first trimester, the state could not prohibit abortions; during the second, the state could regulate abortions to protect maternal health; and during the third, the state could prohibit abortions to demonstrate the state's interest in human life, except those abortions necessary to save the mother's life. ${ }^{23}$ While Roe demonstrated the Court's recognition of women's reproductive rights, in the years after Roe, uncertainty clouded whether the Supreme Court would continue down this path or if the decision would be overturned - allowing states to prohibit abortions. $^{24}$

\section{Creation and Approval of the Undue Burden Standard}

\section{a. Developing the Undue Burden in Planned Parenthood of Southeastern Pennsylvania v. Casey}

In 1992, less than twenty years after Roe, the Court revisited the landscape of abortion jurisprudence. ${ }^{25}$ Since Roe, Justices Souter and Thomas had replaced two of Roe's supporters, Justices Brennan and Marshall; many thought this change in the Court's composition would

legislative enactments must be narrowly drawn to express only the legitimate state interests at stake.") (citations omitted).

20. Id. at $153-56$.

21. Id. at $155-56$.

22. Id. at 155 .

23. Id. at $164-65$.

24. See ERwin Chemerinsky, Constitutional Law: Principles And Policies 859 (5th ed. 2015). The Court's decision in Webster v. Reproductive Health Services indicated that four justices were in favor of overruling Roe. Id. Chief Justice Rehnquist, joined by Justices White and Kennedy wrote a plurality opinion attacking the trimester distinctions in Roe. Id. (citing Webster v. Reproductive Health Servs., 492 U.S. 490, 518 (1989)). In a separate opinion, Justice Scalia suggested that Roe needed to be overruled explicitly. Id. (citing Webster, 492 U.S. at 532 (Scalia, J., concurring in part and concurring in the judgment)). However, Justices Blackmun, Brennan, and Marshall expressed concern over reversing Roe and noted in their dissent that "the signs [of overturning Roe] are evident and very ominous." Id. at 860 (citing Webster, 410 U.S. at 537, 557, 560 (Blackmun, J., dissenting)).

25. See generally Planned Parenthood of Se. Pa. v. Casey, 505 U.S. 833 (1992). 
result in an overruling of Roe. ${ }^{26}$ However, with its decision in Planned Parenthood of Southeastern Pennsylvania v. Casey, the Supreme Court modified traditional abortion analysis of Roe but did not reverse the decision. $^{27}$ Casey represents the end of recognizing abortion as a fundamental right triggering strict scrutiny. ${ }^{28}$ Instead, the Court changed course by deciding that a woman's abortion right is a "protected liberty interest.",29

While the Casey plurality did not overrule $R o e,{ }^{30}$ the Court adopted the "undue burden" analysis to determine the constitutionality of abortion regulations. ${ }^{31}$ In a 5-4 decision, the Court retained and reaffirmed Roe's central holdings - a woman has the right to obtain an abortion before viability without "undue interference from the State," the state has "legitimate interests from the outset of pregnancy in protecting the health of the woman and the life of the fetus," and the state retains power to limit post-viability abortions. ${ }^{32}$ Under Casey, the state retained the power to restrict post-viability abortions so long as exceptions existed in situations where an abortion is necessary to protect the health or life of the woman seeking an abortion. ${ }^{33}$

Even with an affirmation of Roe, the Court abandoned Roe's trimester framework by recognizing an increased importance in the state's interest in protecting the life of the unborn. ${ }^{34}$ The Court replaced

26. See CHEMERINSKY, supra note 24 , at 860 .

27. 505 U.S. at 846 (retaining and reaffirming "the essential holding of" Roe v. Wade); Khiara M. Bridges, Capturing the Judiciary: Carhart and the Undue Burden Standard, 67 WASH. \& LEE L. REV. 915, 917 (2010).

28. See Karen A. Jordan, The Emerging Use of a Balancing Approach in Casey's Undue Burden Analysis, 18 U. PA. J. ConsT. L. 657, 664 (2015).

29. See David L. Rosenthal, Article, Refocusing the Undue Burden Test: Inconsistent Interpretations Pose a Substantial Obstacle to Constitutional Legislation, 31 ISSUES L. \& MED. 3, 910 (2016). As the Court moved away from using the label fundamental rights, the recognition of abortion rights as a liberty interest fits within the jurisprudence of the time. See, e.g., Cruzan v. Dir., Mo. Dep't of Health, 497 U.S. 261, 269, 278-79 (1990) (describing bodily integrity and the right for a competent person to refuse medical treatment as a protected liberty interest and applying a balancing test); see also infra Part III.C.4.a.; Casey, 505 U.S. at 859.

30. See Jordan, supra note 28 , at 660 .

31. Casey, 505 U.S. at 869-77 (plurality opinion).

32. Id. at 846 (majority opinion). While the Court announced that it retained the central holding of Roe v. Wade, Casey abandoned the strict scrutiny standard the Court applied to abortion in Roe and altered the framework for analyzing abortion regulations to be more permissive. Linda J. Wharton et al., Preserving the Core of Roe: Reflections on Planned Parenthood v. Casey, 18 YALE J. L. \& FEMINISM 317, 330 (2006).

33. Casey, 505 U.S. at 846.

34. Id. at 873 (plurality opinion) ("We reject the trimester framework, which we do not consider to be part of the essential holding of Roe... . The trimester framework suffers from these basic flaws: in its formulation it misconceives the nature of the pregnant woman's interest; and in 
the trimester framework with the undue burden analysis to "assess whether state regulation bearing on pre-viability abortion is a permissible or impermissible infringement of a woman's protected liberty interest." 35 Under the undue burden analysis, a finding of an undue burden means that a state's abortion regulation creates a substantial obstacle to a woman's ability to obtain an abortion of a nonviable fetus either through its purpose or effect. ${ }^{36}$ Thus, abortion regulations with the purpose of creating a substantial obstacle are invalid because the mechanism for advancing interest in potential life must be developed to inform, rather than hinder, a woman's free choice. ${ }^{37}$ Similarly, a statute with the legitimate purpose of furthering a valid state interest, which still has the effect of placing a substantial obstacle on a woman's choice to have an abortion, also creates an undue burden. ${ }^{38}$ Therefore, a state may enact regulations to encourage a woman to learn about arguments against having an abortion and to provide a workable framework for a woman making a decision regarding her pregnancy. ${ }^{39}$

Through its decision in Casey, the Court opened the doors for abortion jurisprudence to provide for abortion regulations advancing legitimate state interests. Specifically, Justice O'Connor, writing for the majority, explained that the state has legitimate interests in protecting women's health and protecting the life of the unborn child. ${ }^{40}$ The Court recognized these legitimate interests justify government regulation of abortion access, procedures, providers, and facilities. ${ }^{41}$ Thus, these interests allow the state to enact abortion regulations that limit a woman's right to an abortion. ${ }^{42}$ Furthermore, Justice O'Connor explained the central issue created by abortion regulations is interference with a woman's right to make the ultimate decision of whether or not to have an abortion. ${ }^{43}$ Therefore, so long as they do not create an undue burden on a woman's ability to elect to have an abortion and are

practice it undervalues the State's interest in potential life, as recognized in Roe.") (citations omitted).

35. Jordan, supra note 28, at 663.

36. Casey, 505 U.S. at 877 (plurality opinion) (stating that "[a] finding of an undue burden is a shorthand for the conclusion that a state regulation has the purpose or effect of placing a substantial obstacle in the path of a woman seeking an abortion of a nonviable fetus.").

37. Id.

38. See id.

39. Id. at $872-73$.

40. Id. at 846 (majority opinion).

41. Jordan, supra note 28 , at $661 \&$ n. 14 .

42. See Casey, 505 U.S. at 875-76 (plurality opinion).

43. Id. at 877 . 
reasonably related to the state's legitimate goal, abortion regulations may reflect the state's interest in improving women's health or protecting the life of the unborn child and may be designed to persuade a woman to choose not to have an abortion. ${ }^{44}$

As a result, in applying its undue burden test, the Court held a Pennsylvania statutory provision requiring a woman to provide spousal notice unconstitutional as a violation of the due process clause because it enabled a husband to control, and essentially veto, his wife's choice to have an abortion. ${ }^{45}$ However, the Court upheld the statute's 24-hour waiting period provision, informed consent provision, parental consent provision, and record-keeping provision because these did not impose an undue burden. ${ }^{46}$ By rejecting Roe's application of strict scrutiny to abortion regulations, Casey resulted in states having more leeway to regulate abortions, which led to an increase in abortion laws. ${ }^{47}$ These laws include those pertaining to informed consent, waiting periods, parental approval, and Targeted Regulations of Abortion Providers ("TRAP"). ${ }^{48}$ With the ability to enact these laws, states gained the ability to chip away at a woman's abortion right by enacting laws impacting abortion access, but not imposing an undue burden. ${ }^{49}$

\section{b. Application of the Undue Burden Standard in Stenberg v. Carhart and Gonzales v. Carhart}

Although only three Justices urged the application of the undue burden standard to abortion laws in Casey, in later decisions a majority of Justices embraced the undue burden standard. In Stenberg v. Carhart, the majority announced its approval of the undue burden test, and the

\footnotetext{
44. Id. at 878 .

45. Id. at 897-98 (majority opinion).

46. Id. at 881-87, 889-901 (plurality opinion).

47. Nina Martin, The Supreme Court Decision That Made a Mess of Abortion Rights, MOTHER JONES (Feb. 29, 2016, 7:00 AM), http://www.motherjones.com/politics/2016/02/supreme-courtdecision-mess-abortion-rights; see also Khiara M. Bridges, "Life" in the Balance Judicial Review of Abortion, 46 U.C. DAVIS L. REV. 1285, 1293 (2013) (stating that "when first articulated, [the undue burden standard] was never a particularly tough defender of the abortion right").

48. Neal Devins, How Planned Parenthood v. Casey (Pretty Much) Settled the Abortion Wars, 118 YALE L.J. 1318, 1339-44 (2009) (discussing the change of abortion laws following Casey and how abortion opponents have tested the limits of Casey). TRAP laws are regulations directed specifically at abortion providers and include laws that: (1) single out abortion providers for medically unnecessary regulations, standards, and requirements; (2) needlessly address licensing of abortion clinics or charge large registration fees; or (3) unnecessarily regulate where abortions can occur. ACLU, What TRAP Laws Mean for Women, https://www.aclu.org/files/assets/TRAP_FAQ_FactSheet.pdf.

49. ACLU, supra note 48.
} 
Court applied the test to declare a Nebraska law prohibiting partial birth abortions unconstitutional. ${ }^{50}$ Specifically, the Court noted "the law lacks any exception "for the preservation of the ... health of the mother,",51 and that even with the existence of this exception, the law still imposed an undue burden on a woman's right to terminate a pre-viability pregnancy. ${ }^{52}$ Notably, the Court looked to the law's unintended effecta prohibition of the common pre-viability dilation and evacuation abortion procedure - and found this created a substantial obstacle and therefore imposed an undue burden on a woman's abortion right. ${ }^{53}$

Following Stenberg, the Court in Gonzales v. Carhart used the undue burden test again when evaluating a federal law prohibiting partial birth abortions. ${ }^{54}$ In Gonzales, however, the Court found that the partial birth abortion ban was constitutional because it did not impose an undue burden. ${ }^{55}$ The Court first considered whether the law's purpose was to create a substantial obstacle and concluded that it was not. ${ }^{56}$ Instead, the Court recognized the validity of the law reflecting the legitimate interest in protecting the unborn. ${ }^{57}$ Additionally, the Court considered whether the law's effects resulted in creating an "unconstitutional burden" by not including a health exception, again finding the absence of this burden. ${ }^{58}$ Thus, the Court upheld the regulation, as it did not create an undue burden on a woman's right to an abortion. ${ }^{59}$

\section{B. The Development of a Balancing Approach to the Undue Burden Standard}

\section{Different Interpretations of the Undue Burden Standard}

Over time, the undue burden standard developed in Casey has been subject to differing interpretations and applications from the lower

\footnotetext{
50. 530 U.S. 914,921 (2000).

51. Id. at 930 (alteration in original) (citing Planned Parenthood of Se. Pa. v. Casey, 505 U.S. 833, 879 (1992) (plurality opinion)).

52. Id. at 948 (O'Connor, J., concurring).

53. See id. at 929 (majority opinion); id. 948-50 (O’Connor, J., concurring).

54. 550 U.S. 124, 168 (2007).

55. Id.

56. Id. at 156.

57. See id. at 158 (noting that banning partial-birth abortions furthers the government objectives because the procedure is "laden with the power to devalue human life"); see also Jordan, supra note 28, at 666 (explaining how Gonzales reflected the Court's recognition of the legislatures' ability to advance legitimate state interests).

58. Gonzales, 550 U.S. at 161-65.

59. Id. at 168 .
} 
courts. ${ }^{60}$ Prior to Whole Woman's Health, divisions arose as to how to appropriately apply Casey's undue burden test. ${ }^{61}$ Some courts have applied the undue burden test with a rational basis standard of review, while others use heightened scrutiny. ${ }^{62}$ Furthermore, while some courts have examined both an abortion regulation's purpose and effect, others ignore the putative purpose of the law and only look to the effect of the legislation. ${ }^{63}$ Additionally, a two-part balancing approach encompassing an initial standard of review, which the Supreme Court implicitly demonstrated in Whole Woman's Health,${ }^{64}$ has garnered much discussion and criticism. ${ }^{65}$

The primary division to understanding the undue burden standard occurs when courts evaluate whether a law creates a substantial obstacle to abortion access, even when the law has a legitimate purpose. The language in Casey describing an undue burden is internally contradictory and does not explicitly indicate balancing as suggested by the name undue burden. By equating an undue burden with something having the purpose or effect of creating a "substantial obstacle," the plurality did not indicate that a burden is "undue" because it is excessive in light of its benefits. $^{66}$ Furthermore, the language in Casey also creates confusion around the meaning of substantial obstacle; Casey prohibits laws with "the purpose or effect" of creating substantial obstacles, ${ }^{67}$ but at times only references the effect of creating a substantial obstacle. ${ }^{68}$ While some circuits developed an understanding of the undue burden inquiry to involve balancing benefits and burdens, four circuits approached this

60. Rosenthal, supra note 29, at 9-10; Kali Ann Trahanas, Comment, How the Undue Burden Standard is Eroding Informed Consent, 10 SETON HALl CIR. REV. 231, 260-61 (2013).

61. John A. Robertson, Science Disputes in Abortion Law, 93 TEX. L. REV. 1849, 1852-53 (2015) [hereinafter Science Disputes in Abortion Law].

62. See infra Part II.B.2 (discussing the differing approaches to analysis of the constitutionality of abortion regulations).

63. Rosenthal, supra note 29, at 12 (citing Planned Parenthood of Wis., Inc. v. Van Hollen, 738 F.3d 786, 799 (7th Cir. 2013); Richmond Med. Ctr. for Women v. Herring, 570 F.3d 165, 179 (4th Cir. 2009)).

64. See infra Part II.B.3.

65. See Jordan, supra note 28 , at $718-20$ (providing critiques of courts using the balancing approach).

66. See Metzger, supra note 2, at 2034 (discussing how the use of balancing is implied by the name "undue burden," but that Casey "only analyzes the quantity of burdens imposed").

67. Harvard Leading Case Comment, supra note 2 at 397 (citing Planned Parenthood of Se. Pa. v. Casey, 505 U.S. 833, 877 (1992) (plurality opinion)).

68. Id. 
analysis without any balancing. ${ }^{69}$ Under the non-balancing approach, courts only inquire as to whether the legitimate purpose promoted by the law creates a substantial obstacle to women seeking an abortion. ${ }^{70}$ Whether a law successfully achieves its legitimate interest has no bearing on the law being upheld. ${ }^{71}$ Therefore, under this method, so long as it has a legitimate purpose and is free of substantial obstacles, an abortion regulation does not create an undue burden.

Courts applying a balancing test, however, do the opposite and scrutinize the relationship between an abortion regulation's benefits and the burdens. The Seventh and Ninth Circuit both adopted the use of the balancing test to consider the extent to which a law advances its purported legitimate interest in light of any burdens it places on a woman's ability to obtain an abortion. ${ }^{72}$ Applying a balancing test to the undue burden standard consists of two parts. ${ }^{73}$ First, the legislation regulating abortion must be related to a legitimate state interest under a rational basis analysis. ${ }^{74}$ Second, the legislation "must not have the 'practical effect of imposing an undue burden' on the ability of women to obtain abortions." 75 To determine whether this practical effect exists, courts examine the legislative purpose and practical effect of the regulation together ${ }^{76}$ to balance the state's interests with a woman's right to abortion. ${ }^{77}$

Under the balancing inquiry, a court weighs the regulation's burdens on a woman against the regulation's benefits. Using this analysis, a court deems a regulation unconstitutional when the burden a law imposes on a woman's right to an abortion outweighs the state's justifications for the law. ${ }^{78}$ This generates a scale, whereby a regulation generating high

69. Science Disputes in Abortion Law, supra note 61, at 1853-55. The Fourth, Fifth, Sixth, and Eighth Circuits do not employ a balancing test when determining whether an undue burden exists. Id. at 1853 .

70. $I d$.

71. Id.

72. See id. at 1854; see also Planned Parenthood Ariz., Inc. v. Humble, 753 F. 3d 905, 914 (9th Cir. 2014); Planned Parenthood of Wis., Inc. v. Van Hollen, 738 F.3d 786, 799 (7th Cir. 2013).

73. See, e.g., Van Hollen, 738 F.3d at 795-99 (demonstrating the law first must pass the rational basis analysis and then must not create an undue burden).

74. Id. at 800 (Manion, J., concurring); Rosenthal, supra note 29, at 20.

75. Van Hollen, 738 F.3d at 799, 800 (Manion, J., concurring) (quoting Karlin v. Foust, 188 F.3d 446, 481 (7th Cir. 1999)).

76. Rosenthal, supra note 29 , at 20-21.

77. Humble, 753 F.3d at 912 ("The undue burden test seeks to balance [state] interests with a woman's fundamental right to abortion.").

78. Id. at 914; Van Hollen, 738 F.3d at 795-98 (explaining the analysis of the benefits and the burdens of an abortion regulation requiring admitting privileges). 
benefits for a legitimate state interest requires those opposing the law to demonstrate sufficiently high burdens on a woman's right to access an abortion. ${ }^{79}$ Similarly, if the law confers small benefits to a state interest, it may be unconstitutional with a demonstration of equally small burdens. $^{80}$

\section{Circuit Court Applications of the Balancing Test}

Judge Richard Posner is often noted for applying what is now the balancing test approach to analyzing the constitutionality of an abortion regulation. ${ }^{81}$ In Van Hollen, Wisconsin enacted an abortion regulation requiring admitting privileges for doctors and justified the requirement on the basis of protecting women's health. ${ }^{82}$ After looking at the evidentiary basis for requiring admitting privileges for doctors performing abortions and evaluating the regulation's benefits and burdens, Posner concluded the regulation violated a woman's right to an abortion. ${ }^{83}$ He expressed his application of balancing in the undue burden test with the following:

The feebler the medical grounds, the likelier the burden, even if slight, to be 'undue' in the sense of disproportionate or gratuitous. It is not a matter of the number of women likely to be affected. ... In this case the medical grounds thus far presented . . . are feeble, yet the burden great because of the state's refusal to have permitted abortion providers a reasonable time within which to comply.

With this explanation, Judge Posner articulated how the balancing method of analyzing abortion laws involves an assessment of the evidence provided to support the grounds for enacting the legislation and offered to demonstrate the effect of the law. ${ }^{85}$

Similarly, in Planned Parenthood Arizona, Inc. v. Humble, the Ninth Circuit used a balancing approach to determine that a preliminary injunction for an Arizona law restricting how medical personnel could

\footnotetext{
79. See Van Hollen, 738 F.3d at 798.

80. See id.

81. Jordan, supra note 28 , at $667-72$.

82. 738 F.3d at 789; Jordan, supra note 28 , at 667.

83. See Van Hollen, 738 F.3d at 798 (noting that the medical grounds presented at the time were feeble, and that because the statute did not give abortion providers a reasonable time to comply, the regulation resulted in a great burden on abortion access).

84. Id.

85. See Jordan, supra note 28 , at 669 .
} 
use certain medications to perform abortions was appropriate. ${ }^{86}$ After assuming the Arizona law passed rational basis review, ${ }^{87}$ the court analyzed the law's benefits and burdens. ${ }^{88}$ In its benefits analysis, the court found weak justification for the law based on Arizona's lack of evidence demonstrating "the law furthers any interest in women's health." 89 In contrast, when considering the law's burdens, the court noted evidence of women's preference for medical over surgical abortions, increased costs for medication abortions, potential closures of abortion clinics, increased distances required for women to travel, and delays for women to receive abortions creating health risks. ${ }^{90}$ Balancing these burdens and benefits led the court to find the Arizona law's burdens not justified by any interest. ${ }^{91}$

\section{Supreme Court Approval of a Balancing Analysis: Whole Woman's Health v. Hellerstedt}

As discussed above, prior to Whole Woman's Health, lower courts began analyzing certain abortion regulations aimed to serve a state's interest in health and safety with a balancing test approach. ${ }^{92}$ Before Whole Woman's Health, scholars predicted the necessity of the Court clarifying how to properly analyze abortion regulations. ${ }^{93}$ The Supreme Court's decision in Whole Woman's Health confirmed the use of a balancing test to discern whether an undue burden exists and thus determine the constitutionality of abortion regulation. ${ }^{94}$

86. 753 F.3d 905, 914, 918 (9th Cir. 2014).

87. Id. at 914. This Comment proposes that rational basis review is inappropriate to determine whether a legitimate purpose exists for an abortion regulation. Instead, courts should use a Rational Basis with Bite analysis to first determine whether a purpose is legitimate before applying the balancing test. See infra Part III.

88. Humble, 753 F.3d at 914-16.

89. Id. at $914-15$.

90. Id. at $915-16$.

91. Id. at 917.

92. Jordan, supra note 28, at 666-78.

93. See, e.g., Emma Freeman, Note, Giving Casey Its Bite Back: The Role of Rational Basis Review in Undue Burden Analysis, 48 HARV. C.R.-C.L. L. REV. 279, 279 (2013) (noting that the correct method of implementing the undue burden test is "murky" and that a "tangled body of abortion precedent" exists); Rosenthal, supra note 29, at 20-23 (identifying the existence of a circuit split in methods used to determine the existence of an undue burden); John Robertson, The Undue Burden Test in Texas' Abortion Clinic Regulation, BALKINIZATION (June 16, 2015, 9:00 AM), https://balkin.blogspot.com/2015/06/the-undue-burden-test-in-texas-abortion.html (stating "[i]t is time for the Supreme Court to clarify the 'undue burden' test") [hereinafter Undue Burden Test in Texas].

94. Whole Woman's Health v. Hellerstedt, 136 S. Ct. 2292, 2300 (2016). 
In Whole Woman's Health, the Court found two provisions of the Texas Legislature's House Bill 2 ("H.B. 2") that sought to regulate abortions to be unconstitutional. ${ }^{95}$ The controversy arose from Texas's TRAP laws - which regulated and limited abortion by imposing medical regulations on abortion providers that are not applied to other medical providers. $^{96}$ The Texas abortion provider, Whole Woman's Health, and other abortion providers challenged the validity of the statutory admitting-privileges requirement for doctors performing abortions and the surgical-center requirement. ${ }^{97}$ The admitting-privileges requirement mandated that "[a] physician performing or inducing an abortion... must, on the date the abortion is performed or induced, have active admitting privileges at a hospital that ... is located not further than 30 miles from the location at which the abortion is performed or induced." 98 The surgical-center requirement mandated that "the minimum standards for an abortion facility must be equivalent to the minimum standards adopted under [the Texas Health and Safety Code section] for ambulatory surgical centers." 99 After analyzing each statute's constitutionality, the Court found the statutes unconstitutional-neither created medical benefits great enough to justify the burdens they impose on a woman's access to obtain an abortion. ${ }^{100}$ These burdens, the Court decided, created a substantial obstacle for women seeking pre-viability abortions, which in turn constituted an undue burden that forced the statutes to be unconstitutional. ${ }^{101}$

a. The Fifth Circuit's Interpretation of the Undue Burden Analysis

The Supreme Court's Whole Woman's Health decision reversed the Fifth Circuit's decision in Whole Woman's Health v. Cole, which found, in dicta, that Texas's abortion regulations would not impose an undue burden. ${ }^{102}$ In Whole Woman's Health v. Cole, the Fifth Circuit applied

\footnotetext{
95. Id.

96. Kendra Smale \& Heidi Williamson, Infographic: The State of Abortion Restrictions After Whole Woman's Health, CTR. FOR AM. PROGRess (Aug. 17, 2016), https:/www.americanprogress.org/issues/women/news/2016/08/17/142643/infographic-the-state-ofabortion-restrictions-after-whole-womans-health/; see also supra note 48 (providing examples of TRAP law characteristics).

97. Whole Woman's Health, $136 \mathrm{~S}$. Ct. at $2300-01$.

98. Id. at 2300 (omissions and alteration in original).

99. Id. (alteration in original).

100. Id.

101. Id.

102. Id. at 2320, rev'g Whole Woman's Health v. Cole, 790 F.3d 563, 583-90 (5th Cir. 2015).
} 
the undue burden analysis without any balancing. ${ }^{103}$ The Fifth Circuit's reasoning represents one side of the existing circuit split created by the question of whether the undue burden analysis requires a balancing of benefits and burdens. ${ }^{104}$ In evaluating H.B. 2's requirements, the Fifth Circuit first determined the law was rationally related to the legitimate purpose of protecting the health and welfare of women stated by the bill. $^{105}$ Finding this, the court engaged in its analysis to determine the requirements did not create an undue burden. First, under the purpose prong, the court found a clear legitimate purpose of providing high quality of care to women and protecting women's health. ${ }^{106}$ Notably, the court explicitly rejected the argument that the effects of the law closing most abortion facilities demonstrated an impermissible purpose. ${ }^{107}$ Next, in evaluating the law's effect, the Fifth Circuit criticized the United States District Court for the Western District of Texas's focus on the balance between the burdens and utility of the regulation, which ultimately determined the law would not further the State's interest. ${ }^{108}$ Thus, the Fifth Circuit found H.B. 2's requirements were constitutional, except as applied to one facility. ${ }^{109}$

\section{b. The Supreme Court's Explanation of the Undue Burden Test}

The Supreme Court evaluated H.B. 2's constitutionality by first ${ }^{110}$ discussing the undue burden test as it believed it to be articulated in Casey. ${ }^{11}$ Specifically, the Court announced that the undue burden analysis charges courts with the obligation of considering the burdens a law imposes on a woman's access to abortion in conjunction with the

103. See Cole, 790 F.3d at 572 (stating a law is constitutional under the undue burden standard if "(1) it does not have the purpose or effect of placing a substantial obstacle in the path of a woman seeking an abortion of a nonviable fetus; and (2) it is reasonably related to (or designed to further) a legitimate state interest.") (citing Planned Parenthood of Se. Pa. v. Casey, 530 U.S. 833, 878 (1992) (plurality opinion)).

104. See Undue Burden Test in Texas, supra note 93 (noting the existence of a circuit split where the Seventh and Ninth Circuits apply a balancing test, while the Fourth, Fifth, Sixth and Eighth Circuits reject the use of a balancing test).

105. Cole, 790 F.3d at 584 .

106. Id.

107. Id. at 585 ("[C]ourts 'do not assume unconstitutional legislative intent even when statutes produce harmful results.'”) (quoting Mazurek v. Armstrong, 520 U.S. 968, 972 (1997)).

108. Id. at 586 .

109. Id. at 567 .

110. The Court began its analysis of the undue burden standard after addressing the issue of claim preclusion on plaintiffs' claims and declaring that res judicata did not bar any claims. Whole Woman's Health v. Hellerstedt, 136 S. Ct. 2292, 2304-09 (2016).

111. Id. at 2309 . 
benefits, or legitimate state interests, achieved by the regulation. ${ }^{112}$ Furthermore, noting Casey, the Court explained the emphasis that courts must place on evidence and arguments occurring during trial as opposed to giving deference to legislative findings. ${ }^{113}$ For a court to appropriately use evidence presented at trial to determine whether an abortion regulation creates an undue burden, it should consider and weigh the evidence as opposed to replacing the legislature's judgment with its own. ${ }^{114}$ Using this approach, the Supreme Court evaluated lower courts' applications and analyses of the undue burden test.

Without stating its use of the balancing approach to determine whether H.B. 2 created an undue burden, the Court's evaluation of the legislation reflected a balancing test. First, the Court looked at the purpose behind the regulation and its effects to determine the existence of any purported benefits to a legitimate state interest. ${ }^{115}$ Second, the Court looked to whether evidence demonstrated any "substantial obstacle in the path of a woman's choice." 116 Thus, the Court considered the burdens of the regulation in conjunction with the benefits promoted by the laws. ${ }^{117}$ With this explanation of the undue burden test, the Court flatly rejected the Fifth Circuit's interpretation of Casey; the Fifth Circuit had mandated that courts provide rational basis deference to abortion legislation and should not "balance the wisdom or effectiveness of a law against the burdens the law imposes." 118

\section{c. Application of the Undue Burden Test to Texas's Admitting- Privileges Requirement}

In its application of the undue burden test, the Court found Texas's admitting-privileges requirement in H.B. 2 unconstitutional. The Court

\footnotetext{
112. Id. (citing Planned Parenthood of Se. Pa. v. Casey, 505 U.S. at 877-79 (1992) (plurality opinion)).

113. Id. at 2310 .

114. Id.

115. See id. at 2310-11.

116. Id. at 2312 (citing Casey, 505 U.S. at 877 (plurality opinion)).

117. Id. at 2309 .

118. Whole Woman's Health v. Lakey, 769 F.3d 285, 297 (5th Cir. 2014); see Whole Woman's Health, 136 S. Ct. at 2309-10 (criticizing the Fifth Circuit's test that "is wrong to equate the judicial review applicable to the regulation of a constitutionally protected personal liberty with the less strict review applicable where, for example, economic legislation is at issue"); see also Linda Greenhouse $\&$ Reva B. Siegel, The Difference a Whole Woman Makes: Protection for the Abortion Right After Whole Woman's Health, 126 YALE L.J.F. 149, 154-56 (2016) (discussing how the Fifth Circuit refrained from using an evidentiary inquiry to determine whether the medical benefits supported the state's claim of protecting a mother's health outweighed the regulations' burden).
} 
concluded the United States District Court for the Western District of Texas was correct in finding that the legislation imposed an undue burden on a woman's right to an abortion. ${ }^{119}$ Texas argued the new regulation advanced the state's "legitimate interest in protecting women's health" ${ }^{120}$ because the purpose of the admitting-privileges requirement was to help guarantee women could easily access a hospital should any abortion complications arise. ${ }^{121}$ During its analysis, the Court evaluated whether the evidence presented at the district court level was sufficient for the district court to find that the new regulation created an undue burden on the woman's right to choose. ${ }^{122}$ Based on the combination of expert testimonies and research studies presented to the district court, the Court first held that in comparison to the prior Texas law relating to admitting privileges, the new regulation did not do any more to advance the State's legitimate interest in protecting women's health. ${ }^{123}$ The Court found a lack of benefit in advancing the legitimate interest because a variety of evidence demonstrated that prior to the act's passage, abortions resulted in low rates of complications and the State admitted it did not know of "a single instance [where] the new requirement would have helped even one woman obtain better treatment."124

Following review of evidentiary findings on the law's impact on advancing protections of women's health, the Court looked at evidence of the admitting-privileges requirement's creation of obstacles preventing a woman from exercising her choice with respect to an abortion. ${ }^{125}$ Evidence pointed to the relationship between the new admitting-privileges requirement and closure of abortion clinics. ${ }^{126}$ Doctors had difficulty obtaining admitting privileges due to lack of necessity of transferring abortion patients to hospitals ${ }^{127}$ and inconsistent requirements to receive privileges. ${ }^{128}$ This was sufficient evidence to

\footnotetext{
119. Whole Woman's Health, 136 S. Ct. at 2310-11.

120. Id. at 2311 .

121. Id.

122. See id.

123. Id.

124. Id. at 2311-12.

125. Id. at 2312-14.

126. Id. at 2312 .

127. Id. at 2312 (citing and discussing Brief of Amici Curiae Soc'y of Hospital Med. \& Soc'y of OB/GYN Hospitalists in Support of Petitioners, Whole Woman's Health v. Cole, 136 S. Ct. 499 (2015) (No. 15-274)).

128. Id. at 2312-13 (citing and discussing Brief for Amici Curiae Am. Coll. of Obstetricians \& Gynecologists, Am. Med. Assoc., Am. Acad. of Family Physicians, Am. Osteopathic Assoc., \& Am. Acad. of Pediatrics in Support of Petitioners, Cole, 136 S. Ct. 499 (2015) (No. 15-274), Brief of
} 
support the notion that as a result of the new requirement half of Texas's clinics closed, causing fewer doctors, increased wait times, and increased driving distance for women. ${ }^{129}$ In addition to finding no apparent health benefit of the regulation, the Court determined the evidence "adequately support[ed] the District Court's 'undue burden' conclusion," and found the admitting-privileges requirement unconstitutional. ${ }^{130}$

\section{d. Application of the Undue Burden Test to Texas's Surgical-Center Requirements}

The Court applied the undue burden test to conclude that Texas's surgical-center requirements in H.B. 2 were unconstitutional. Similar to the proposed admitting-privileges regulations, the surgical-center requirement added heightened requirements to previously existing laws, ${ }^{131}$ and Texas argued it served the legitimate state interest of protecting women's health. ${ }^{132}$ In evaluating the evidence presented in support of requiring abortion facilities to meet ambulatory surgicalcenter standards, the Court found support for the notion that the requirement does not provide its purported benefits and is unnecessary. ${ }^{133}$ Women receiving medical abortions obtain no benefit from surgicalcenter requirements because potential complications almost always arise after leaving the facility; ${ }^{134}$ surgical abortions do not require the level of sterilization required for other surgeries; ${ }^{135}$ and complications arising following abortions most often require hospitalization rather than treatment that could be provided at a surgical center. ${ }^{136}$

The Court continued examining evidence to evaluate whether the surgical-center requirements placed a "substantial obstacle" in a woman's path to receive an abortion. Here, sufficient evidence existed to support the notion that this requirement would have reduced the number of abortion facilities to seven or eight, which would have been

\footnotetext{
Amici Curiae Med. Staff Prof'ls in Support of Petitioners, Cole, 136 S. Ct. 499 (2015) (No. 15274)).

129. Id. at 2313 .

130. Id.

131. Id. at 2314. Among others, these requirements included specifications relating to nursing staff size, building dimensions, and electrical and ventilation requirements. Id. at 2314-15.

132. See id. at 2315 .

133. Id. at $2315-16$.

134. Id.

135. See id. at 2315-16 ("But abortions typically involve either the administration of medicines or procedures performed through the natural opening of the birth canal, which is itself not sterile.").

136. See id. at 2316 .
} 
unable to meet the abortion demand in Texas. ${ }^{137}$ Statistics demonstrated that clinics would have had to perform five times the number of abortions than they performed prior to the regulation. ${ }^{138}$ The cost increases that would have been required for currently licensed abortion facilities to meet standards of a surgical center and the increased capacity these facilities would have been forced to take on, indicated that any new licensed facilities per the new regulation would not make up for the lack of abortion facilities after closures occurred. ${ }^{139}$ Thus, the Court affirmed that the substantial obstacles to women seeking abortions outweigh the few, if any, benefits to women's health conferred by the surgical-center requirement. ${ }^{140}$ In turn, this resulted in the Court finding that Texas's surgical-center requirement created an undue burden and was unconstitutional. ${ }^{141}$

\section{e. The Dissent-A Departure from Casey's Articulation of an Undue Burden?}

As expected with a Supreme Court decision on abortion, the case resulted in two dissents - one by Justice Thomas, the other by Justice Alito. ${ }^{142}$ While Justice Alito's dissent focused on arguing that the Court should have dismissed petitioners' claims on res judicata grounds, ${ }^{143}$ Justice Thomas's dissent specifically called attention to the majority's application of the undue burden standard. ${ }^{144}$ According to Thomas's dissent, the majority "radically" changed the undue burden test from Casey in three ways. ${ }^{145}$

137. Id. at 2316

138. Id. (" $[T]$ he number of abortions that the clinics would have to provide would rise from '14,000 abortions annually' to ' 60,000 to 70,000 ' ....” (quoting Whole Woman's Health v. Cole, 790 F.3d 563, 589-90 (5th Cir. 2015), rev'd, Whole Woman's Health, 136 S. Ct. at 2320 (2016))).

139. Id. at 2318 .

140. See id.

141. Id.

142. Id. at 2321 (Thomas, J., dissenting); id. 2330 (Alito, J., dissenting).

143. Id. at 2330-2342 (Alito, J., dissenting). Alito further argued that the plaintiffs failed to show the admitting-privileges and surgical-center requirements caused the abortion facilities to close because other reasons existed for their closure. Id. at 2342-50. Alito's dissent concluded by criticizing how the majority ignored the statute's "extraordinarily broad severability clause" before enjoining parties. $I d$. at $2350-53$.

144. Id. at 2321 (Thomas, J., dissenting) ("Whatever scrutiny the majority applies ... it bears little resemblance to the undue-burden test the Court articulated in [Casey] and its successors.").

145. Id. at 2324 (noting that "[e]ven taking Casey as the baseline... the majority radically rewrites the undue-burden test.”). 
First, Justice Thomas pronounced that the majority's utilization of a balancing test contradicts Casey. ${ }^{146}$ Instead of weighing benefits and burdens, Thomas described that in Casey, the question was whether there was a substantial obstacle, and that in post-Casey decisions, the Court specifically rejected considering a lack of benefits in its undue burden analysis. ${ }^{147}$ Second, Justice Thomas criticized the majority's unwillingness to defer to legislative findings with respect to questions involving medical uncertainty. ${ }^{148}$ Thomas criticized the majority for relying on the evidence and arguments in judicial proceedings instead of trusting the legislature to resolve these questions. ${ }^{149}$ Third, he noted how the majority requires states to demonstrate by more than a rational basis the law's connection to a legitimate interest even in the absence of substantial burdens on a woman's access to an abortion. ${ }^{150}$ Although the majority did not specify its specific standard of review, Justice Thomas commented how the majority increased the states' burden to a level that looks similar to strict scrutiny rejected in Casey. ${ }^{151}$

Whole Woman's Health now exists as the most recent and controlling Supreme Court Case in abortion jurisprudence. While the decision itself does not offer an explicit explanation of the undue burden test, it provides a platform to decipher a clear test to use when applying the undue burden standard to laws restricting abortions.

\section{ANALYSIS}

Whole Woman's Health allowed the Court to provide further insight as to how to apply the undue burden standard to determine the constitutionality of abortion regulations. In its articulation of a balancing of burdens and benefits of an abortion regulation to determine the existence of an undue burden, the Court offered support for a more rigorous analysis of abortion regulations. Building on the Supreme Court's decision in Whole Woman's Health, courts should use a Rational Basis with Bite Balancing Test to evaluate abortion regulations to

\footnotetext{
146. Id.

147. Id. at 2324-25 ("Mazurek also deemed objections to the law's lack of benefits 'squarely foreclosed by Casey itself."” (quoting Mazurek v. Armstrong, 117 S. Ct. 1865, 1867 (1997) (per curiam)).

148. Id. at 2325 ("Before today, this Court had 'given state and federal legislatures wide discretion to pass legislation in areas where there is medical and scientific uncertainty." (quoting Gonzales v. Carhart, 550 U.S. 124, 163 (2007)).

149. Id.

150. Id. at $2325-26$.

151. Id. at 2326 .
} 
account for the protection of a woman's liberty interest in a right to an abortion. Under this formulation of the undue burden test, courts should first scrutinize an abortion regulation's purpose with a heightened form of rational basis - Rational Basis with Bite - and conclude by balancing the regulation's burdens and benefits to determine the strength of the relationship between the law's purpose and effects. This appropriately conforms to abortion and liberty interest jurisprudence, and in doing so protects a woman's right to an abortion by invalidating unnecessary laws created with the purpose of creating a substantial obstacle to abortion access.

\section{A. The Much Needed End of Inconsistencies Among Courts Attempting to Apply the Undue Burden Standard to Abortion Regulations}

Whole Woman's Health marks a clarification to, and a change in the direction of, the abortion jurisprudence landscape. Whether the Court appropriately followed prior Supreme Court precedent has no bearing on the fact that now lower courts must follow the guidance of the Supreme Court in its analysis of the undue burden test when judging the constitutionality of abortion regulations. By employing a balancing test to determine the existence of an undue burden, Whole Woman's Health begins to appropriately address issues surrounding the constitutional methods for regulating abortions in an ever-changing society.

As abortion regulations are highly politicized laws, the balancing test expressed in Whole Woman's Health takes some controversy out of the decisions. Instead of giving a high deference to the stated legislative rationale behind an abortion regulation, the balancing test appropriately replaces this deference with the requirement to examine hard evidence and statistics to consider whether a legitimate state interest is necessarily reached through a regulation or whether the state interest can be attained without harming a woman's right to an abortion in the process. This acknowledgement of a rigorous analysis is important because the Supreme Court's decision comes at a time when it is difficult to find unreasonable, and therefore unlawful, reasons for enacting regulations that restrict abortions. ${ }^{152}$ Therefore, Whole Woman's Health appropriately addresses a woman's right to an abortion as a protected liberty interest, rather than something greater or lesser.

Moreover, now that the Supreme Court has alluded to using an endsmeans scrutiny test combined with a balancing to determine if a law

152. Robertson, supra note 61 , at 1852-53. 
creates an undue burden, it is necessary to decipher how this multifaceted test should be explained and applied in the fluctuating jurisprudence of abortion regulations. On the most fundamental level, the test for whether an abortion regulation constitutes an undue burden should be approached as a two-part test. The first prong should consist of a moderately rigorous ends-means scrutiny evaluation-Rational Basis with Bite - and the second prong should consist of a balancing of burdens and benefits to determine whether or not an abortion regulation actually advances its purposes, or instead creates an undue burden, making the law unconstitutional.

A test encompassing these elements achieves what the test's nameundue burden - suggests it should do as a test applied to determine the constitutionality of regulations impacting a woman's liberty interest in the right to an abortion. The phrase "undue burden" lends itself to the meaning that a burden on a woman's right to an abortion is allowed, only if it is found to not be one that is "undue." Under Casey's undue burden standard, which lower courts have struggled to apply since its inception, the Court created confusion as to what constitutes an undue burden. ${ }^{153}$ Clarifying the undue burden test to require an explicit rational basis with bite analysis and balancing of burdens and benefits to determine whether a law truly furthers a legitimate purpose without imposing an undue burden helps alleviate this issue. ${ }^{154}$

\section{B. Developing a Rational Basis with Bite Balancing Test}

Though not plainly stated in the opinion, Whole Woman's Health lends itself to the development of an appropriately rigorous, two-part test to analyze the constitutionality of abortion regulation. To initially determine whether the law is rationally or reasonably related to its purported purpose, the end-means scrutiny used should mirror "Rational Basis with Bite," or "Rational Basis with Teeth." ${ }^{55}$ This should then be followed by a burdens-benefits balancing test, which evaluates the law's effects to determine whether it creates an undue burden - that is, whether

153. See Chemerinsky, supra note 24, at 863 ("The key question after Casey, Stenberg, and Gonzales v. Carhart is what constitutes an undue burden on the right to abortion."); see also supra Part II.B.1-2.

154. See Wharton et al., supra note 32, at 331-39 (arguing that Casey demonstrates the authors of the joint opinion intended to develop a rigorous standard that evaluates the effect of an abortion regulation on women and the government's purpose in enacting the regulation).

155. See supra note 14. 
the benefits the law purports to achieve outweigh the obstacle placed in the path of a woman seeking to obtain an abortion.

1. The Classic Ends-Means Scrutiny: Rational Basis with Bite

Under the first part of this Rational Basis with Bite Balancing Test, a court determines whether a rational basis exists for the piece of abortion legislation. First, the party challenging the law must show the absence of a rational basis for the law. Here, a court will determine if the legislature enacted the regulation solely based on a bare desire to harm a woman's right to an abortion or to prevent a woman receiving an abortion. As rational basis with bite is a form of ends-means scrutiny, the law's purported end, or goal, must represent a legitimate purpose. As established in Casey, two permissible legitimate purposes exist for abortion regulations - the state's interest in protecting potential human life and the state's interest in protecting women's health. ${ }^{156}$ On the other hand, the mere purpose of placing a substantial obstacle in the path of a woman receiving an abortion is illegitimate. ${ }^{157}$ To demonstrate the law's illegitimate purpose, the party opposing the law may point to, and the court may look to, the law's legislative history and text to demonstrate the existence of an illegitimate purpose.

If a court finds the existence of a bare desire to harm, then the analysis stops because this is not a legitimate purpose; and thus, the law is unconstitutional even without the application of the balancing. On the other hand, if a bare desire to harm does not exist, the law must further be evaluated under the balancing prong of the Rational Basis with Bite Balancing Test to determine whether or not the law results in an undue burden on the right to an abortion.

However, assuming the court finds the existence of a legitimate end, under the rational basis with bite test, the means must also be rationally or reasonably related to this end. ${ }^{158}$ A party opposing a regulation can demonstrate improper means by demonstrating the law's irrationality through evidence pertaining to the over or under inclusiveness of the means or the availability of other alternatives to achieve the purported

\footnotetext{
156. Planned Parenthood of Se. Pa. v. Casey, 505 U.S. 833, 846 (1992).

157. See id.

158. See Gayle Lynn Pettinga, Note, Rational Basis with Bite: Intermediate Scrutiny by Any Other Name, 62 IND. L. J. 779, 787-800 (1987) (discussing situations where the Court looked for a law's legitimate purpose, but went on to apply a rational basis with bite analysis).
} 
end. ${ }^{159}$ Evaluating both the ends and means is key because it may reveal whether the law's purported purpose is mere pretext for a bare desire to harm a woman's right to an abortion.

Justice Ginsburg's concurrence in Whole Woman's Health reflects use of a rational basis with bite inquiry into an abortion regulation. Her concurrence began by recognizing Texas's argument that H.B. 2's restrictions were constitutional because they served the legitimate purpose of protecting the health of women who experience abortion complications. ${ }^{160}$ The restrictions, however, did not have a strong connection to achieving this purpose. ${ }^{161}$ Ginsburg's analysis of the constitutionality of the admitting-privileges and surgical-center requirements specifically called to attention evidence depicting the rarity of the complications and the discrepancy between the level of danger associated with abortion compared to other procedures lacking similar requirements. ${ }^{162}$ Here, evaluating both the ends and the means of the regulations led to the discovery that these laws did "little or nothing for health" and instead created barriers to abortion access. ${ }^{163}$ As such, the law's means had no rational connection to the stated ends; instead, the regulations imposed barriers to abortion and were unconstitutional.

\section{The Final Undue Burden Consideration: A Balancing Act}

Assuming the law passes the above rational basis with bite test, ${ }^{164} \mathrm{a}$ court should then conduct a balancing test to determine the constitutionality of the abortion law based on the determination of whether an undue burden exists. The court should evaluate the law's actual effects and determine the relationship between the purported benefits the law seeks to achieve and the incidental burdens it places on a woman's right to abortion access. The relationship found between the claimed beneficial purpose of the law and its actual effects is key to properly protecting a woman's right to an abortion.

In this Rational Basis with Bite Balancing Test formulation, the balancing component consists of weighing abortion regulations' benefits

\footnotetext{
159. See id. at 794.

160. Whole Woman's Health v. Hellerstedt, 136 S. Ct. 2292, 2320 (2016) (Ginsburg, J., concurring).

161. Id. at 2321 .

162. Id. at $2320-21$.

163. Id. at 2321 (quoting Planned Parenthood of Wis., Inc. v. Schimel, 806 F.3d 908, 921 (7th Cir. 2015)).

164. See supra Part III.B.1.
} 
and the burdens. This necessarily requires a court to undergo a two-part analysis - first, a measurement of both the benefits and the burdens generated by the law; and second, a weighing of the burdens and benefits to determine whether an undue burden exists. In determining a law's effects in the forms of the resulting benefits and burdens, the courts should conduct a highly fact-intensive analysis, looking at evidence such as expert testimony, empirical studies, and data. ${ }^{165}$

Analyzing an abortion regulation's burdens and benefits should consist of both the factual inquiry and a consideration of the strength of the relationship between the ends-means scrutiny as determined in the rational basis with bite analysis. As suggested by courts using a balancing test in the abortion context, relevant facts to a regulation's benefits and burdens include: the number of women likely affected by the regulation, ${ }^{166}$ resulting clinic closures, waiting times, cost changes, the law's necessity, improvements to women's health, and the number of complications resulting from a given procedure. ${ }^{167}$ Furthermore, courts should consider the strength of the correlation between an abortion regulation's legitimate purpose and the means used to accomplish the purpose - as found in the rational basis with bite analysis - in evaluating the burdens a law imposes "together with" 168 the benefits conferred by the law. Here, a stronger correlation between the ends and means suggests a stronger benefit.

After fully identifying burdens and benefits, a court should then conduct the balancing inquiry, which is where courts will have the most discretion. Under the balancing inquiry, a court should "compare the extent of the burden a law imposes on a woman's right to abortion with the strength of the state's justification for the law."169 When a law imposes a great burden on a woman's right to an abortion, the state's justification for enacting it must in turn be strong as demonstrated by the regulation's necessity and its success at achieving its purpose. Conversely, the stronger a state's justification for the law, the greater the burden must be before it becomes undue. Concluding with this balancing test ultimately results in the Rational Basis with Bite Balancing Test ensuring that unnecessary regulations neither have the

165. See supra Part II.B.3 (discussing how Whole Woman's Health looked to evidence of H.B. 2's burdens and benefits).

166. Planned Parenthood of Wis., Inc. v. Van Hollen, 738 F.3d 786, 798 (7th Cir. 2013).

167. Whole Woman's Health, $136 \mathrm{~S}$. Ct. at 2316-18.

168. Id. at 2309 (citing Planned Parenthood of Se. Pa. v. Casey, 505 U.S. 833, 887-98 (1992)).

169. Planned Parenthood Ariz., Inc. v. Humble, 753 F.3d 905, 912-14 (9th Cir. 2014). 
purpose nor the effect of creating substantial obstacles constituting an undue burden on a woman's right to an abortion.

\section{Support for the Rational Basis with Bite Balancing Test}

While the Court in Whole Woman's Health did not explicitly state it applied a Rational Basis with Bite Balancing Test to declare Texas's laws unconstitutional, this test clarifies and improves upon the Court's reasoning. By completing separate inquiries for the purpose and effect of the law, this test promotes the idea that abortion regulations not only actually serve a legitimate state interest but that they are also necessary to do so. In doing so, the Rational Basis with Bite Balancing Test appropriately protects a woman's right to an abortion and falls within the broader realm of liberty interest jurisprudence.

\section{The Language of Whole Woman's Health Suggests Using a Rational} Basis with Bite Balancing Test

The majority opinion in Whole Woman's Health can be construed to reflect an implicit application of Rational Basis with Bite analysis, followed by an explicit balancing test. The Court in Whole Woman's Health identified both that a pure rational basis review was inappropriate to apply in the context of abortion regulations ${ }^{170}$ and the inherent necessity of a balancing test to evaluate whether an undue burden exists. By first identifying the purpose of the abortion regulations-protecting the mother's health ${ }^{171}$-and evaluating the relationship between the regulation's surgical-center and admitting-privileges requirement and its purpose, the Court engaged in an implicit rational basis with bite analysis. Here, the Court stressed the importance of an actual connection between the regulations and Texas's purported state interest. Through this searching scrutiny, the Court recognized the attenuated connection between the end Texas stated as the regulation's purpose and the means of achieving these ends - nothing suggested the new law advanced Texas's legitimate interest in protecting women's health. ${ }^{172}$

170. See Harvard Leading Case Comment, supra note 2, at 405 (“[T]he Whole Woman's Health majority flatly and formally rejected rational basis review, requiring instead a more searching purpose analysis.").

171. Whole Woman's Health, 136 S. Ct. at 2311.

172. See id. ("We have found nothing in Texas' record evidence that shows that, compared to prior law (which required a 'working arrangement' with a doctor with admitting privileges), the new law advanced Texas' legitimate interest in protecting women's health.”). 
Following the implicit rational basis with bite analysis, the Court demonstrated the use of a balancing test identified as inherently necessary at the outset of the opinion. To begin its discussion of the unconstitutionality of the regulations, the Court stated its conclusion that "neither [the surgical-center nor admitting-privilege requirements] confer[] medical benefits sufficient to justify the burdens upon access that each imposes." 173 To reach this conclusion, the Court found the laws created substantial obstacles to abortion access because of a decrease in the number of clinics available and a drop in the quality of care provided to patients. These substantial obstacles equate to the burdens created by the laws. Thus, the Court concluded that when it weighed these burdens against the minimal benefits created by the regulations, an undue burden existed.

2. The Necessity of Using Rational Basis with Bite to Initially Evaluate an Abortion Regulation's Purpose

Using rational basis with bite to analyze the purpose of an abortion regulation prior to applying a balancing test is appropriate because it charges courts with evaluating whether a legitimate purpose exists for the law at the forefront of the analysis. As opposed to assuming a law passes the scrutiny, as with rational basis analysis, rational basis with bite protects a woman's abortion right by actually looking for a nexus between the stated ends and means to determine the law's true legitimacy. When courts analyze the purpose of abortion regulations under rational basis scrutiny, this rarely creates a barrier for unnecessary laws unsupported by a legitimate purpose. ${ }^{174} \mathrm{~A}$ rational basis with bite test, on the other hand, requires heightened scrutiny, and thus promotes a deeper inquiry into the law's purpose. ${ }^{175}$ Therefore, use of this endsmeans scrutiny analysis recognizes that laws regulating abortion containing an invalid purpose are facially unconstitutional. ${ }^{176}$

Courts should analyze the purpose of abortion laws under rational basis with bite because abortion rights parallel other rights that have caused courts to apply a heightened rational basis test. While the Supreme Court has never specifically articulated what triggers use of a

\footnotetext{
173. Id. at 2300 .

174. Undue Burden Test in Texas, supra note 93.

175. See Pettinga, supra note 158 , at $799-800$ (describing rational basis with bite as a form of heightened scrutiny as opposed to rational basis).

176. See id. at 800 (noting that rational basis with bite leads to unconstitutional laws that would be valid under a rational basis analysis).
} 
scrutiny mirroring rational basis with bite, the Court appears to apply it when it is hesitant to declare the use of strict scrutiny but believes there is action harming equality protected by the Fourteenth Amendment. ${ }^{177}$ Additionally, scholars identify two triggers calling for heightened rational basis ${ }^{178}$ - laws impacting targeted and vulnerable individuals and laws impacting important rights. ${ }^{179}$ Considering both the people abortion legislation impacts and the recognition of a woman's right to an abortion as an important right demonstrates why rational basis with bite should be the first part of the test to determine the constitutionality of abortion regulations.

First, those targeted by abortion regulations - both individual women receiving an abortion and abortion providers - are vulnerable groups of individuals, worthy of having laws impacting them scrutinized for legitimacy. Rational basis with bite, a less deferential form of the rational basis test, has been used to invalidate laws when the Court suspects "animus" against a certain group. ${ }^{180}$ This analysis of individuals with a specific animus, or who otherwise lack political power, originated and is applied in Equal Protection cases. However, even so, women seeking to exercise their right to an abortion still face a stigma, which should allow this heightened scrutiny to transfer over at the forefront of the Rational Basis with Bite Balancing Test. Additionally, the Court's initial willingness to analyze abortion laws under strict scrutiny further demonstrates the necessity of using some form of heightened inquiry to determine whether a law's purpose is to create a substantial obstacle for a woman's right to an abortion.

177. City of Cleburne v. Cleburne Living Ctr., 473 U.S. 432, 471-72 (1985) (Marshall, J., concurring in part and dissenting in part); see also Freeman, supra note 93, at 302 (examining potential triggers of the rational basis with bite analysis).

178. Freeman, supra note 93, at 302-03.

179. Sarah Finnane Hanafin, Comment, Legal Shelter: A Case for Homelessness as a Protected Status Under Hate Crime Law and Enhanced Equal Protection Scrutiny, 40 STETSON L. REV. 435, 468 (2011) (discussing the application of a "searching scrutiny" to laws impacting individuals who experience unfair treatment); Pettinga, supra note 158, at 801 (describing how rational basis with bite is triggered when "review[ing] legislation that burdens an important right of a group at least approaching quasi-suspect status"); see also Freeman, supra note 93, at 302-03 (explaining instances where courts have used a heightened rational basis review).

180. See, e.g., United States v. Windsor, 133 S. Ct. 2675, 2695-96 (2013) (using a less deferential form of rational basis when evaluating the purpose of the Defense of Marriage Act and its effect on homosexuals); Romer v. Evans, 517 U.S. 620, 635 (1996) (applying a less deferential form of rational basis to evaluate a law classifying homosexuals and declaring the law unconstitutional because it failed to further a "proper legislative end"); City of Cleburne, 473 U.S. at 450 (declaring a Texas law requiring a special permit for operating a group home for the mentally handicapped unconstitutional because it is based on an "irrational prejudice against the mentally [handicapped]"). 
Furthermore, even though the Court no longer recognizes the abortion right as fundamental, the Court continues to recognize a woman's right to an abortion as important. In Casey, the language reflecting the Court's desire to give "real substance to the woman's liberty" to elect to have an abortion that stemmed from the "urgent claims of the woman to retain the ultimate control over her destiny and her body" ${ }^{181}$ acknowledges the substantial nature of the abortion right. In addition to this passionate and empowering language, the Casey Court's determination that states must have a legitimate, profound interest to interfere with this right signifies its importance. Most recently, Whole Woman's Health serves as a reminder of the importance of a woman's right to an abortion. Justice Breyer, writing for the majority, confirmed this by explaining how the Fifth Circuit erroneously applied the rational basis analysis to the laws and that the circuit court was incorrect to apply a lower level of constitutional review where a protected personal liberty interest was at issue. ${ }^{182}$ Therefore, as abortion regulations impact women exercising their right to an abortion - an oftentimes unpopular groupand the Court heralds the right to an abortion as important, it follows that using a rational basis with bite analysis in the undue burden test appropriately scrutinizes an abortion regulation's purpose.

\section{The Balancing Component Adds Protection to a Woman's Right to an Abortion}

While a rational basis with bite analysis affords more protection than a rational basis test under which the assumption is that a law will pass, even when an abortion regulation has a legitimate purpose, courts should continue the analysis to ensure that any burden created is not undue. The appropriate mechanism for this is to apply the balancing test. This balancing, demonstrated in Whole Woman's Health and other judicial opinions, ${ }^{183}$ captures the appropriate method for protecting a woman's abortion right by evaluating the interaction between the purpose and effects of an abortion regulation.

The use of this balancing appropriately follows from Whole Woman's Health, which stressed the importance of considering burdens and benefits together to evaluate the presence or absence of an undue burden. ${ }^{184}$ Doing so appropriately evaluates both the purpose and effects

181. Planned Parenthood of Se. Pa. v. Casey, 505 U.S. 833, 869 (1992) (plurality opinion).

182. Whole Woman's Health v. Hellerstedt, 136 S. Ct. 2292, 2309-10 (2016).

183. See supra, Part II.B.2-3.

184. Whole Woman's Health, 136 S. Ct. at 2309-10. 
of a law. It thus ensures that enacted regulations not only have an appropriate purpose, but are also necessary to achieve that interest, which depends "on whether and how well it serves the state's interest." 185 Focusing on the necessity of abortion regulations is not a new concept. In Casey, Justices O'Connor, Kennedy, and Souter recognized the necessity of abortion regulations, ${ }^{186}$ which in turn supports using a balancing approach to determine whether a law truly achieves the necessary purpose. Use of a balancing test guarantees that laws furthering legitimate interests in potential life or protecting women's health are calculated to achieve the purpose, rather than enact barriers to the right. Thus, this protects the abortion right as a liberty interest, rather than a right that can be affected by laws having only a rational basis.

Moreover, considering factual evidence of a law's purpose and effects is necessary in the balancing test because this recognizes that similarly drafted regulations may impact the abortion right differently. An appropriate analysis of the undue burden test is context-specific, which will account for variances of circumstances affecting the severity of burdens and strength of justifications among states. ${ }^{187}$ As discussed by Justice O'Conner in Casey, lower courts engaging in a factual inquiry consisting of expert testimony, facts, empirical studies, and common sense are important to create consistent application of the undue burden standard. ${ }^{188}$ Courts fulfill their responsibility of protecting a woman's liberty interest by relying on these forms of evidence, rather than giving great deference to the legislature. Focusing on a factual inquiry, as opposed to legislative deference, supports the important function courts have in determining whether a burden on a woman's right to an abortion is truly undue in light of the benefits incurred by enacting the legislation. This structured approach will result in courts exercising the appropriate amount of discretion, while ensuring states appropriately enact regulations with either the intent of protecting a mother's health or the potential life of the fetus.

\footnotetext{
185. Planned Parenthood of Ariz., Inc. v. Humble, 753 F.3d 905, 913 (2014).

186. See Casey, 505 U.S. at 878 (plurality opinion) (noting that unnecessary health regulations resulting in a substantial obstacle on abortion access imposes an undue burden).

187. Humble, 753 F.3d at 914 (citing Tucson Woman's Clinic v. Eden, 379 F.3d 531, 541 (9th Cir. 2004)).

188. See Casey, 505 U.S. at 880-901 (majority and plurality opinions) (discussing in detail each statute at issue and the District Court's findings).
} 
4. A Rational Basis with Bite Balancing Test Parallels the Supreme Court's Approach to Protecting Other Liberty Interests

Using a balancing test, preceded by a rational basis with bite analysis, to determine the constitutionality of abortion regulations is appropriate not only because it affords the appropriate protection to a woman's right to an abortion but also because it fits well within the context of liberty interest jurisprudence. Although liberty interests do not receive the same level of protection as fundamental rights, since courts do not evaluate laws impacting liberty interests under strict scrutiny, ${ }^{189}$ the Supreme Court has demonstrated a trend to afford liberty interests a level of protection above rational basis review. Notably, these tests reflect the Court's willingness to implement a balancing approach to evaluating legislation impacting liberty interests. When using this balancing approach to evaluate a state action's burdens on liberty interests, courts determine whether constitutional rights have been violated by weighing the burden on the right against the relevant interest asserted by the state. ${ }^{190}$ Thus, using a balancing approach for the undue burden evaluation of abortion regulations appropriately protects both a woman's right to abortion access and the state's interests. As such, a balancing approach follows the Supreme Court's trend of using balancing tests to evaluate laws impacting the recognized liberty interests in bodily integrity and intimate relationships.

a. The Abortion Right Parallels an Individual's Liberty Interest in Bodily Integrity

In recent decades, the Court has recognized an individual's liberty interest in bodily integrity. When the Court recognized this interest in Cruzan v. Missouri Department of Health, ${ }^{191}$ the Court provided support for use of a liberty interest balancing test. By neither labeling the right as "fundamental," nor suggesting the use of a lower level of scrutiny, the Court left the approach to this liberty interest open to interpretation. Within the case, the Court declared a person has a constitutionally protected right to refuse unwanted medical care found under the liberty of the due process clause. ${ }^{192}$ Following this recognition, however, Chief Justice Rehnquist's majority opinion also accepted that states have an

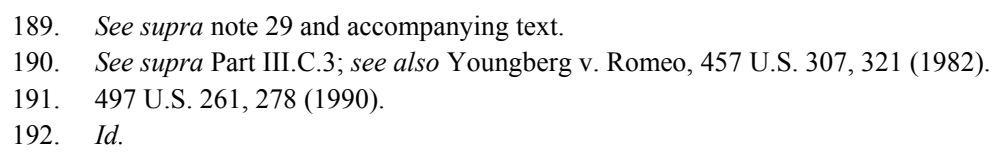


interest in both protecting life and ensuring that an individual truly wants to end treatment before the decision to suspend it is made. ${ }^{193}$ Specifically, he noted Missouri could "legitimately seek to safeguard the personal element of [ending treatment] through the imposition of heightened evidentiary requirements." 194 With this statement, Cruzan represents that to determine whether a law unconstitutionally burdens this liberty interest, a court must weigh the evidence demonstrating an individual's interest in ending medical treatment against the state's inherent interest in life and ascertaining the validity of the individual's desires. Therefore, this opinion represents the necessity of using a form of balancing test to evaluate regulations impacting any liberty interest, especially those involving highly personal decisions and the state's, possibly conflicting, interests.

The parallels between the language used when analyzing abortion regulations and the language the majority used in Cruzan demonstrate how the analogous nature of the two liberty interests warrants a parallel test be used to evaluate the two types of regulations. Similar to abortion jurisprudence where states have a recognized interest in both protecting a mother's health and an interest in the potential life of the fetus, states have an interest in both protecting life and ensuring that a patient truly desired to end treatment. Additionally, the Court also recognized that this choice is "deeply personal," 195 a concept frequently used when discussing a woman's right to an abortion. ${ }^{196}$ The Court further demonstrated the connection between abortion jurisprudence and bodily integrity when, in its Casey opinion, it cited Cruzan as a case exemplifying how the state's legitimate interest in protecting life does not result in complete denials of individual liberty claims. ${ }^{197}$ Thus, these similarities naturally lead to the appropriateness of using a comparable balancing approach to analyzing the competing burdens and benefits proffered in regard to abortion regulations.

\footnotetext{
193. Id. at $281-82$.

194. Id. at 281.

195. Id. at 281 .

196. See, e.g., Planned Parenthood of Se. Pa. v. Casey, 505 U.S. 833, 851 (1992) (discussing how abortion is a matter "involving [a] most intimate and personal choice[]").

197. Id. at 857 (citing Cruzan, 497 U.S. at 278).
} 
b. The Abortion Right Is Similar to an Individual's Liberty Interest in Intimate Relationships

When the Court began recognizing an individual's right to privacy in the form of intimate sexual relationships, the Court employed a similar test in cases involving an individual's right to end medical care. In Lawrence v. Texas, the Court also arguably applied a balancing test in the context of homosexual sodomy. ${ }^{198}$ After recognizing intimate sexual relationships are within the right of privacy, and thus a protected liberty interest, the Court declared a Texas state law banning homosexual conduct to be unconstitutional. ${ }^{199}$ In doing so, the majority again neither explicitly articulated a scrutiny or framework used to determine the law's unconstitutionality. However, the Court demonstrated a type of balancing in its evaluation of the law. The Court exhibited this balancing by searching for whether a legitimate state interest existed which could "justify [Texas's] intrusion into the personal and private life of the individual." 200 Affirming that Texas viewing "a particular practice as immoral [was] not a sufficient reason for upholding a law prohibiting the practice, $" 201$ the Court found the law did not further a state interest, and thus was unconstitutional. ${ }^{202}$ Here, the Court's use of "justify" and "sufficient" the state's intrusion into an individual's personal and private life, while others will fall flat.

With this decision, the Court recognized the necessity of using a balancing test to assess the tumultuous relationship between a state and an individual's liberty interest in a right to privacy. Recognizing the need for balancing signifies the trend of using balancing tests to assess the constitutionality of laws impacting liberty interests protected by the Due Process Clause once a court finds the law furthers a legitimate state interest. A woman's right to an abortion and an individual's right to sexual intimacy are similar because both involve a degree of choice that the state also has an interest in. Whereas the Supreme Court has

\footnotetext{
198. 539 U.S. 558, 577-79 (2003).

199. Id. at 578.

200. Id.

201. Id. at 577 (quoting Bowers v. Hardwick, 478 U.S. 186, 216 (1986) (Stevens, J., dissenting)).

202. Id. at $577-78$.

203. Although basing her opinion in the Equal Protection Clause, rather than the Due Process Clause of the Fourteenth Amendment, Justice O'Connor's concurrence emphasizes that the finding of moral disapproval is an insufficient rationale to justify Texas's criminalization of homosexual sodomy. Id. at 579-83 (O’Connor, J., concurring).
} 
recognized the state's interest in protecting unborn life and a woman's health in the realm of abortion, the Court has similarly recognized that states have an interest in controlling certain aspects of sexual intimacy. ${ }^{204}$ Therefore, it follows that incorporating a balancing test to analyzing abortion legislation follows the Court's trend of recognizing that, if justifiable, strong legitimate state interests can outweigh burdens on an individual's constitutionally protected liberty interest.

At this point in time, the Supreme Court has demonstrated its intent to recognize a woman's right to an abortion as a protected liberty interest. ${ }^{205}$ The Court has neither made any attempt to revert back to its analysis in Roe and recognize this right as fundamental-protected by strict scrutiny - nor has it indicated this right is left unprotected by the Constitution. ${ }^{206}$ With this trend, the Court will continue to recognize a woman's right to an abortion as a constitutionally protected liberty interest. Therefore, similar to an individual's liberty interest in refusing medical treatment and having intimate sexual relationships, analyzing abortion regulations under the Rational Basis with Bite Balancing Test appropriately fits within the Supreme Court's broader approach to understanding, recognizing, and protecting individuals' liberty interests.

5. Applying the Rational Basis with Bite Balancing Test to Abortion Regulations

a. The Importance of Consistently Applying the Rational Basis with Bite Balancing Test

There is a great necessity for courts to apply the balancing test approach to the undue burden test consistently among all types of abortion regulations. Courts should not differentiate between protecting a legitimate interest in human life and a legitimate interest in the woman's health. Although these interests are different at their core, differentiating the two would result in an inconsistent mechanism for evaluating abortion regulations. Furthermore, because the Rational Basis with Bite Balancing Test creates a higher burden for abortion regulations to overcome, applying a different process of evaluating the regulation

204. See id. at 578 (discussing that the case did not involve minors, persons who could be injured or refuse consent, or public conduct or prostitution, which would have an impact on society at large).

205. See Whole Woman's Health v. Hellerstedt, 136 S. Ct. 2292, 2309-10 (2016) (continuing to evaluate abortion regulations under an undue burden standard).

206. See id. 
implicitly would serve to place a fluctuating level of importance on a woman's right to abortion access.

The Court in Whole Woman's Health specifically applied a balancing test to legislation enacted with the stated purpose of serving a state's legitimate interest in the health of a mother. ${ }^{207}$ It is important to note that, unlike the regulations introduced by H.B. 2, other laws do not necessarily have the effect of closing abortion clinics and resulting in an undue burden on a woman's right to an abortion. ${ }^{208}$ Instead, these laws may impact a woman's ability to obtain an abortion by limiting the types of abortions medical providers can perform, requiring multiple visits to a clinic, increasing costs, or requiring women receive information regarding the impact of an abortion. As such, applying a Rational Basis with Bite Balancing Test to dismemberment abortion bans demonstrates how this test can serve as a framework to determine the constitutionality of these laws by scrutinizing the law's purpose and the relationship between the purpose and effects.

b. Evaluating Dismemberment Abortion Bans Using the Rational Basis with Bite Balancing Test

States, including Kansas, Oklahoma, Mississippi, and Alabama, have recently started introducing legislation and enacting laws known as dismemberment abortion bans. ${ }^{209}$ Dismemberment abortions are generally defined as "knowingly dismembering a living unborn child and extracting such unborn child one piece at a time from the uterus." 210 This definition encompasses abortions known as dilation and evacuation (" $\mathrm{D}$ \& E") procedures, which are the primary means of an abortion for women receiving an abortion during the second trimester. ${ }^{211}$ Under the Rational Basis with Bite Balancing Test, these laws may be unconstitutional.

\footnotetext{
207. See supra Part II.B.3.

208. See supra Part II.B.3.c-d. (discussing the effects of Texas's H.B. 2 abortion regulations).

209. Fact Sheet, National Right to Life, Dismemberment Abortion Bans, at 1 (Jan. 27, 2017), http://www.nrlc.org/uploads/stateleg/StateLawsDismembermentAbortionBans.pdf. While some of these laws have already been challenged and received preliminary injunctions pending cases being heard in state courts, others have already been enacted. See id. at 2.

210. Dahlia Lithwick, Dismembered Protections, Slate (Apr. 15, 2015), http://www.slate.com/ articles/news_and politics/jurisprudence/2015/04/kansas_and_oklahoma_abortion_bans_second_tri mester_abortions_will_be_more.html.

211. Hodes \& Nauser, MDs, P.A. v. Schmidt, 368 P.3d 667, 669 (Kan. Ct. App. 2016), review granted, No. 114,153 (Kan. Apr. 11, 2016).
} 
An analysis under only the rational basis with bite prong is likely not indicative of whether a law is unconstitutional, which results in an application of both prongs of the Rational Basis with Bite Balancing Test. Protecting fetal life exists as the legitimate purpose for dismemberment abortion bans. ${ }^{212}$ With this legitimate end, any ban on abortion will be strongly connected to this goal by limiting abortions and respecting human life. ${ }^{213}$ While the legitimate purpose of respecting fetal life exists for dismemberment bans, the means used to achieve this purpose indicates the possibility of these laws serving as a pretext for placing obstacles in the path of women to have an abortion during the second trimester. Here, the language in dismemberment abortion ban regulations not only graphically describes the procedure, but is broad enough to include $\mathrm{D} \& \mathrm{E}$ procedures. ${ }^{214}$ Therefore, the over inclusiveness reveals that while the laws may achieve a legitimate purpose, this end may serve as a pretext.

As the rational basis with bite analysis will unlikely invalidate dismemberment abortion bans, a balancing of the benefits and burdens analysis is the next step in determining whether dismemberment abortion bans create an undue burden. First, banning a type of abortion is connected with the legitimate interest of protecting the life of unborn child, which demonstrates a benefit. However, the success of achieving this purported benefit may be considered slight because only about ten percent of abortions occur during the second trimester; most women receive abortions during the first trimester. ${ }^{215}$ For example, in Kansas, second-trimester D \& E procedures accounted for approximately eight percent of abortions during 2014. ${ }^{216}$ Therefore, these laws will result in few procedures actually being affected, detracting from the strength of the benefits.

212. See supra note 204 and accompanying text; see also Gonzales v. Carhart, 550 U.S. 124, 158 (2007) (explaining how the state may regulate procedures to further its legitimate interest in "regulating the medical profession in order to promote respect for life, including life of the unborn").

213. See Gonzales, 550 U.S. at 158 (noting that D \& E procedures are "laden with the power to devalue human life"); see also Bridges, supra note 47, at 1334-37 (2013) (discussing the strength of the state's interest in protecting fetal life).

214. For an example of language in a statute that has now been called into question, see, e.g., Kan. Stat. ANN. § 65-6742(b)(1) (Supp. 2016), which defines "dismemberment abortion" as "knowingly dismembering a living unborn child and extracting such unborn child one piece at a time from the uterus through the use of clamps, grasping forceps, tongs, scissors or similar instruments that, through the convergence of two rigid levers, slice, crush or grasp a portion of the unborn child's body in order to cut or rip it off."

215. Hodes \& Nauser, 368 P.3d at 669.

216. Lithwick, supra note 210. 
While the purpose and benefits created by dismemberment abortion bans reflect a legitimate interest in protecting the life of the unborn, they also generate burdens on a woman's access to abortion. Women will face heavy burdens with the inability to elect D \& E procedures because $D \& E$ procedures account for at least ninety-five percent of secondtrimester abortions. ${ }^{217}$ Moreover, D \& E procedures are recognized as the safest procedure for terminating second-trimester pregnancies. In the absence of $\mathrm{D} \& \mathrm{E}$ procedures, women seeking a second-trimester abortion will be faced with alternatives such as a medically induced labor, which risk more complications than D \& Es. ${ }^{218}$ Thus, dismemberment bans result in women having fewer safe alternatives.

After the determination of the benefits and burdens of dismemberment abortion bans occurs, the two must be balanced to determine whether an undue burden on a woman's right to an abortion exists. A weighing of the burdens against the benefits suggests that while a legitimate purpose exists for enacting the laws, few actual benefits exist. As D \& Es account for very few abortion procedures, this suggests that the benefits legislatures propose may not outweigh the resulting burdens. Conversely, women seeking to obtain a secondtrimester abortion would face many burdens on abortion access because they would be required to seek alternative, potentially more dangerous procedures. Thus, under a balancing of the benefits and burdens, there is potential the benefits do not account for the burden, resulting in an undue burden. Therefore, under a Rational Basis with Bite Balancing Test, dismemberment laws may create an undue burden on a woman's right to an abortion and be unconstitutional.

\section{CONCLUSION}

By not approving the Fifth Circuit's interpretation of Casey's analysis of abortion regulations as requiring only a rational basis scrutiny and instead demonstrating a weighing of the benefits and burdens of abortion regulations, the Supreme Court in Whole Woman's Health

217. Susan Berry, Planned Parenthood Says Mississippi Ban on Dismemberment Abortion Is 'Attack on Women's Health Care', BREITBART (Apr. 19, 2016), http://www.breitbart.com/abortion/ 2016/04/19/planned-parenthood-says-mississippi-ban-dismemberment-abortion-attack-womenshealth-care/ (noting that ninety-six percent of all second trimester abortions are achieved through D $\&$ E procedures).

218. See Rachel Perry \& Bryna Harwood, Options for Second-Trimester Termination, CONTEMPORARY OB/GYN (Nov. 1, 2013), http://contemporaryobgyn.modernmedicine.com/ contemporary-obgyn/content/tags/abortion/options-second-trimester-termination; see also Hodes \& Nauser, 368 P.3d at 677-78 (discussing the relative risks of D \& E procedures and alternatives). 
paved the way for a new era of abortion jurisprudence. The decision indicates that courts no longer can evaluate the purpose and effects of the legislation separately. Instead, courts must ensure that the legislation's purpose is necessary and justified in light of the burdens it creates. Therefore, in deciding Whole Woman's Health, the Supreme Court demonstrated its desire to continue recognizing a woman's right to an abortion as a protected liberty interest and to not shirk in affording this right the protection it demands.

Using Whole Women's Health as a mechanism for the development of a Rational Basis with Bite Balancing Test demonstrates the need to continue to protect a woman's liberty interest in her right to an abortion. By first searching for a nexus between a law's stated purpose in achieving a state's legitimate interest and the means it uses to accomplish these ends, courts at the forefront ensure the legitimacy of the regulations purpose. With courts focusing on verifiable evidence and giving less deference to legislatures, the Rational Basis with Bite Balancing Test prevents unnecessary abortion laws from hiding in the shadows of purported legitimate interests that only exist to cover the actual illegitimate purposes of many forms of abortion legislation. As the Court's make-up hangs in the balance, uncertainty looms as to whether the trend will be to continue protecting a woman's right to an abortion. ${ }^{219}$ However, unless the Court chooses to overturn years of abortion jurisprudence, the Rational Basis with Bite Balancing Test appropriately protects a woman's right to abortion while remaining true to abortion regulation precedent.

219. See Lawrence Hurley \& Steve Holland, Trump Picks Conservative Judge Gorsuch for Supreme Court, REUTERS (Feb. 1, 2017), http://www.reuters.com/article/us-usa-court-trumpidUSKBN15F1OW (noting that President Donald Trump's nominee to the Supreme Court, Neil Gorsuch, could restore the Court's conservative majority and shape rulings on various issues, including abortion); Adam Liptak \& Matt Flegenheimer, Neil Gorsuch Confirmed by Senate as Supreme Court Justice, N.Y. TIMES, Apr. 7, 2017, https://www.nytimes.com/2017/04/07/us/politics/ neil-gorsuch-supreme-court.html?_r=0. 